\title{
Immunohistochemical expression of p63 in esophageal Barrett's adenocarcinoma
}

\author{
TADASHI HARA ${ }^{1}$, HIROSHI KIJIMA ${ }^{2}$, SOICHIRO YAMAMOTO ${ }^{1}$, YOSIFUMI KISE ${ }^{1}$, TOMOKO HANASHI ${ }^{1}$, \\ TAKAYUKI NISHI ${ }^{1}$, OSAMU CHINO ${ }^{1}$, HIDEO SHIMADA $^{1}$, MAKIKO TANAKA $^{3}$, \\ SADAKI INOKUCHI ${ }^{3}$ and HIROYASU MAKUUCHI ${ }^{1}$
}

\author{
${ }^{1}$ Department of Surgery, Tokai University School of Medicine, Isehara, Kanagawa 259-1193; ${ }^{2}$ Department of Pathology, \\ Hirosaki University School of Medicine, Hirosaki, Aomori 036-8562; ${ }^{3}$ Department of Critical Care and \\ Emergency Medicine, Tokai University School of Medicine, Isehara, Kanagawa 259-1193, Japan
}

Received March 21, 2008; Accepted May 23, 2008

\begin{abstract}
. p63, which has recently been identified as a member of the p53 gene family, plays many important roles in human tissue functions. We examined p63 expression patterns in esophageal Barrett's adenocarcinoma, including early-stage cancers, as well as its clinicopathological significance. Immunoreactivity for p63 was detected in $45.8 \%(11 / 24)$ of the adenocarcinomas; all cases were focally positive. p63 was detected not only in the in situ carcinomatous components or intramucosal carcinomas, but also in the invasive carcinomatous regions of the p63-positive cases. Immunohistochemical expression was correlated with clinicopathological features; i.e., lymph node metastasis, lymphatic invasion and venous invasion were found in $72.7 \%(\mathrm{p}<0.01)$, $100 \%(\mathrm{p}<0.05)$ and $90.9 \%(\mathrm{p}<0.05)$ of the p63-positive cases, respectively, at a significantly high incidence compared with the p63-negative cases. We also analyzed the relationship between p63 and p53 expression. No diffuse expression of p63 was detected, although diffuse expression of p53 was detected in $50.0 \%(12 / 24)$ of the adenocarcinomas. The role of the p63 gene is thought to be different in esophageal Barrett's adenocarcinoma compared with esophageal squamous cell carcinoma. p63 immunoreactivity was most useful as a predictor of lymph node metastasis.
\end{abstract}

\section{Introduction}

Barrett's mucosa is an inflammatory and reactive condition in which the normal squamous mucosa of the esophagus is

Correspondence to: Dr Hiroshi Kijima, Department of Pathology, Hirosaki University School of Medicine, 5 Zaifu-cho, Hirosaki, Aomori 036-8562, Japan

E-mail: hkijima@cc.hirosaki-u.ac.jp

Key words: Barrett's esophagus, Barrett's adenocarcinoma, p63, immunohistochemistry replaced by a metaplastic columnar epithelium $(1,2)$. The disease may be caused by the esophageal reflux of digestive fluid, including gastric juice and/or bile, and is ordinarily lined by a gastric-type epithelium with or without intestinal metaplasia. Several studies have reported a high incidence of adenocarcinoma arising in Barrett's mucosa, and have analyzed and compared it to the morphological characteristics of esophageal adenocarcinoma $(3,4)$. Previously, in esophageal Barrett's adenocarcinoma and non-neoplastic Barrett's mucosa around the carcinoma, we analyzed the distribution of mucin and CD10 and evaluated proliferative activity with a Ki-67 labeling index (LI) $(5,6)$. It is suggested that Barrett's esophageal mucosa with intestinal metaplasia and a high $\mathrm{Ki}-67 \mathrm{LI}$ is the premalignant lesion with the most impact (6).

p63, a homologue of the tumor-suppressor p53, is highly expressed in the basal or progenitor layers of squamous epithelia, such as the skin, esophagus and exocervix (7-9). In the stratified epithelia, p63 is essential for the proliferative potential of stem cells (10). In contrast, p63 expression is absent or restricted in colonic, mammary or prostatic epithelia (7). Recent studies have reported p63 expression predominantly in basal cell carcinomas, squamous cell carcinomas and transitional cell carcinomas, but not in adenocarcinomas, including gastric and colonic cancers (7,11-14). We have also analyzed the expression and histological distribution of p63 and p53 in esophageal squamous cell carcinomas, and reported that the results suggest the p63 gene plays a major role in the carcinogenesis of human esophageal squamous cells and in the growth of the carcinoma (15). However, the expression patterns of p63 in esophageal Barrett's adenocarcinoma have yet to be extensively analyzed.

In the present study, we examined the expression and histological distribution of p63 and p53 protein in esophageal Barrett's adenocarcinoma, including early-stage cancers, and discussed the clinicopathological significance of the disease.

\section{Materials and methods}

Esophageal tissue specimens. All tissue specimens were obtained through surgical resections of esophageal Barrett's adenocarcinoma at Tokai University Hospital. Twenty-four 
cases of Barrett's adenocarcinoma were examined in this study. All were histopathologically defined as a columnar epithelium of the esophagus, i.e. Barrett's esophagus, using routine hematoxylin and eosin-stained sections. The adenocarcinomas were classified according to the TMN system (16). All esophageal specimens were rapidly fixed in $10 \%$ buffered formalin and routinely embedded in paraffin for 14-48 h for histological and immunohistochemical analysis. Tumor invasion, venous invasion and lymphatic invasion were examined on $4-\mu \mathrm{m}$ sections stained with hematoxylin and eosin.

Immunohistochemical analysis. Sections (4 $\mu \mathrm{m})$ were deparaffinized, and endogenous peroxidase activity was quenched by incubation in $0.3 \% \mathrm{H}_{2} \mathrm{O}_{2}$ in methanol for $30 \mathrm{~min}$ (17-20). Sections were autoclaved (ES-215, high-pressure steam sterilizer, Tomy, Japan) at $121^{\circ} \mathrm{C}$ for 4 min for antigen retrieval. Non-specific binding was blocked with normal sheep serum (Cosmo Bio Co. Lit., Tokyo, Japan) in phosphatebuffered saline (PBS), and then slides were incubated with anti-p63 (clone 4A4, 1:1600; PharMingen International, San Diego, CA, USA) or anti-p53 monoclonal antibody (clone DO7, 1:20; Novo Castra, Newcastle, UK) overnight at $4^{\circ} \mathrm{C}$. Immunoreactivity was detected using the peroxidase-labeled streptavidin-biotin (LSAB) method (Dako A/S, Copenhagen, Denmark) (21). Slides were subsequently incubated with biotinylated anti-mouse $\operatorname{Ig}(\mathrm{Fab})_{2}$ antibody (Amersham International plc., Buckinghamshire, UK) at a dilution of 1:100 for $60 \mathrm{~min}$, followed by detection using streptavidinconjugated horseradish peroxidase.

Assessment of p63 and p53 expression. Tumor cells with nuclei containing brown immunoreaction products were counted as positive for p63 or p53 protein expression. Immunohistochemical expression patterns of p63 or p53 were divided into 4 groups as follows: (i) negative expression, (ii) sporadic expression with $<5 \%$ of cancer cells positive for $\mathrm{p} 63$ or p53, (iii) focal expression with $5-50 \%$ of cancer cells positive for $\mathrm{p} 63$ or $\mathrm{p} 53$, and (iv) diffuse expression with $>50 \%$ of cancer cells positive for p63 or p53. Cases of positive expression included (iii) focal expression and (iv) diffuse expression.

Statistical analysis. The $\chi^{2}$ test and Fisher's exact test were used for comparisons between group frequencies. Statistical significance was defined as $\mathrm{p}<0.05$.

\section{Results}

Immunoreactivity for p63 was detected in the nucleus but not in the cytoplasm of cells. The results of immunohistochemical analysis are summarized in Table I. Immunoreactivity in the cancer tissues was found in $11(45.8 \%)$ of the 24 esophageal Barrett's adenocarcinomas examined; all cases were focally positive (Fig. 1). In this study, p63 expression was found not only in T1 tumors, but also in cases of invasive carcinoma. Immunohistochemical expression patterns of p63 and p53 are summarized in Table II. No diffuse expression of p63 was detected, although diffuse p53 expression was detected in $50.0 \%(12 / 24)$ of the adenocarcinomas.
Table I. p63 immunoreactivity and the clinicopathological features of esophageal Barrett's adenocarcinoma.

\begin{tabular}{|c|c|c|c|}
\hline & \multicolumn{2}{|c|}{ p63 expression (\%) } & \multirow[b]{2}{*}{$\mathrm{p}$-value } \\
\hline & $\begin{array}{l}\text { Negative/ } \\
\text { sporadic }\end{array}$ & $\begin{array}{l}\text { Positive } \\
\text { (focal) }\end{array}$ & \\
\hline Esophageal cancer $(n=24)$ & $13(54.2)$ & $11(45.8)$ & \\
\hline \multicolumn{4}{|l|}{ Primary tumor } \\
\hline $\mathrm{T} 1$ & $10(66.7)$ & $5(33.3)$ & \\
\hline $\mathrm{T} 2$ & $1(50.0)$ & $1(50.0)$ & \\
\hline T3/T4 & $2(28.6)$ & $5(71.4)$ & \\
\hline \multicolumn{4}{|l|}{ Differentiation } \\
\hline Well & $9(56.3)$ & $7(43.7)$ & \\
\hline Moderate & $4(50.0)$ & $4(50.0)$ & \\
\hline Poor & $0 \quad(0.0)$ & $0 \quad(0.0)$ & \\
\hline \multicolumn{4}{|l|}{$\begin{array}{l}\text { Regional lymph node } \\
\text { metastasis }\end{array}$} \\
\hline$(-)$ & $11(78.6)$ & $3(21.4)$ & \\
\hline$(+)$ & $2(20.0)$ & $8(80.0)$ & $<0.01$ \\
\hline \multicolumn{4}{|l|}{ Lymphatic invasion } \\
\hline$(-)$ & $5(100.0)$ & $0 \quad(0.0)$ & \\
\hline$(+)$ & $8 \quad(42.1)$ & $11(57.9)$ & $<0.05$ \\
\hline \multicolumn{4}{|l|}{ Venous invasion } \\
\hline$(-)$ & $7(87.5)$ & $1(12.5)$ & \\
\hline$(+)$ & $6(37.5)$ & $10(62.5)$ & $<0.05$ \\
\hline
\end{tabular}

We analyzed the relationship between p63 expression and clinicopathological features, such as depth of tumor invasion, tumor differentiation and lymphatic/venous invasion (Table I). p63 was frequently detected in the cancer cells $(45.8 \%, 11 / 24)$ regardless of the depth of tumor invasion or the differentiation of the tumor. Lymph node metastasis, lymphatic invasion and venous invasion were found in $72.7 \%(8 / 11)(\mathrm{p}<0.01)$, $100 \%(11 / 11)(\mathrm{p}<0.05)$ and $90.9 \%(10 / 11)(\mathrm{p}<0.05)$ of the p63-positive cases, respectively, at a significantly high incidence compared with the p63-negative cases.

\section{Discussion}

Using biopsy specimens, Hall et al detected the expression of p63, $\Delta \mathrm{Np} 63 \alpha$ and p53 in esophageal Barrett's adenocarcinomas (22). In the present study, we examined p63 and p53 expression immunohistochemically in esophageal Barrett's adenocarcinoma, and analyzed its clinicopathological significance using surgically resected specimens. Focally-positive p63 immunoreactivity was detected in $45.8 \%$ (11/24) of the adenocarcinomas, while no cases of diffuse expression were found in the present study. These patterns of p63 expression were similar to those of a study by Geddert et al (23). On the other hand, p63 immunoreactivity was detected at a high frequency in human esophageal squamous cell carcinomas, as shown in our previous study (15). p63 expression was found not only 

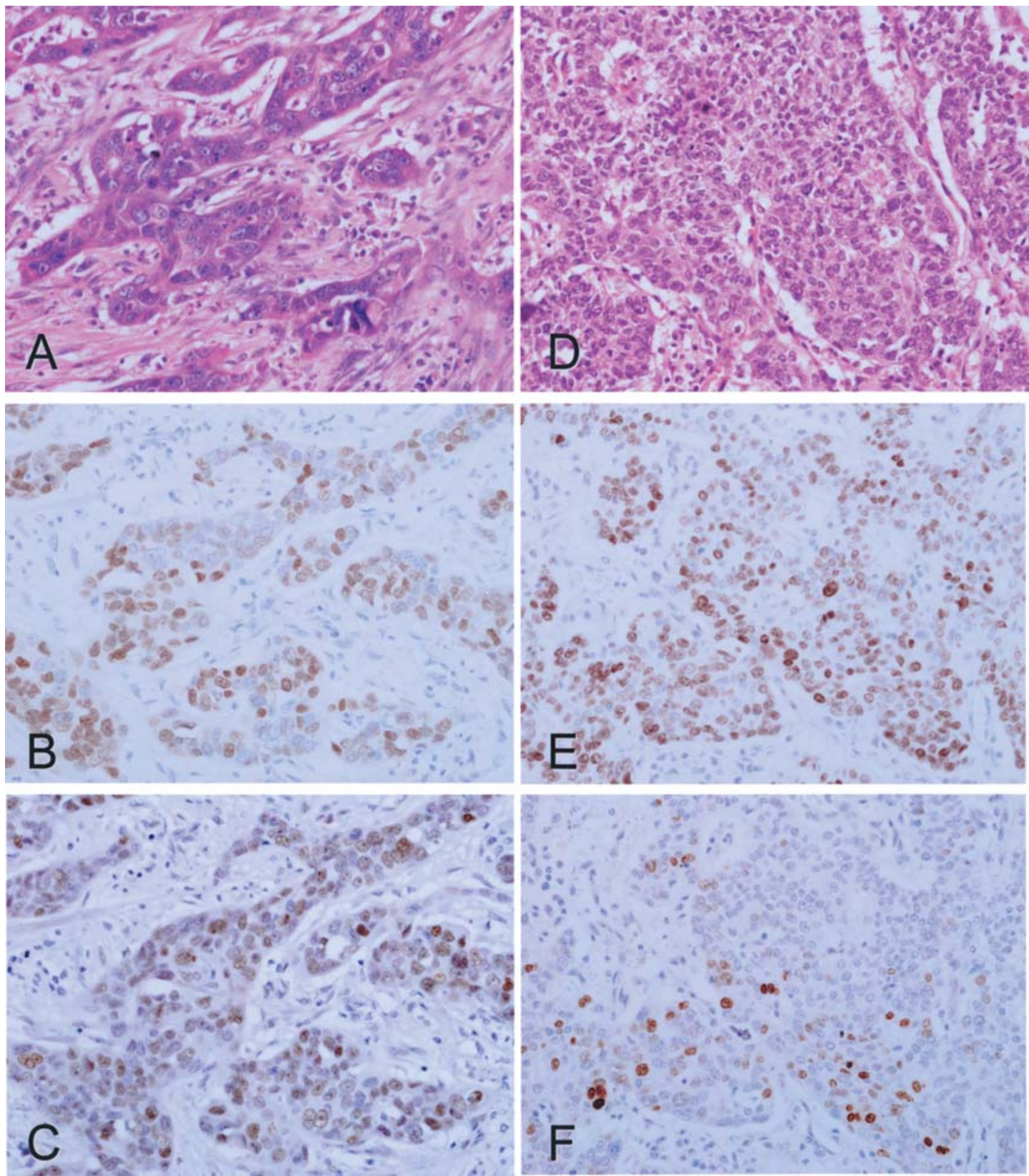

Figure 1. Microscopic findings of p63- and p53-positive esophageal Barrett's adenocarcinomas. (A) The carcinoma invaded the esophageal wall (hematoxylin and eosin). (B) Focal p63 immunoreactivity was detected in the nuclei of the carcinoma cells (the same case as A, LSAB method). (C) Diffuse p53 immunoreactivity was detected in the nuclei of the carcinoma cells (the same case as A, LSAB method). (D) The carcinoma invaded the esophageal wall (hematoxylin and eosin). (E) Focal p63 immunoreactivity was detected in the nuclei of the carcinoma cells (the same case as D, LSAB method). (F) Focal p53 immunoreactivity was detected in the nuclei of the carcinoma cells (the same case as D, LSAB method).

Table II. Immunoreactivitiy for p63 and p53 in esophageal Barrett's adenocarcinoma.

\begin{tabular}{llccr}
\hline & \multicolumn{3}{c}{$\mathrm{p63}$} & \\
\cline { 3 - 4 } & & $\begin{array}{c}\text { Negative/ } \\
\text { sporadic }\end{array}$ & $\begin{array}{c}\text { Positive } \\
\text { (focal) }\end{array}$ & Total \\
\hline p53 & Negative/sporadic & 4 & 2 & 6 \\
& Positive (focal) & 4 & 2 & 6 \\
Positive (diffuse) & 5 & 7 & 12 \\
Total & 13 & 11 & 24 \\
\hline
\end{tabular}

in the $\mathrm{T} 1$ tumors, but also in invasive carcinomas. Lymph node metastasis, lymphatic invasion and venous invasion were frequently found in the p63-positive adenocarcinomas. This is the first report to analyze the relation between p63 expression and pathological factors, such as vascular invasion, in esophageal Barrett's adenocarcinoma using surgically resected specimens.

The p63 gene, located at $3 q 27-29$, is a member of the p53 gene family. Its products have amino acid sequences similar to those of p53 gene products $(9,24)$. Unlike p53, p63 gene products are divided into two groups: (i) an isotype with a transactivating domain (TA) in the $\mathrm{N}$-terminal region and (ii) a $\Delta \mathrm{N}$ isotype ( $\Delta \mathrm{Np} 63)$, which lacks the TA domain $(9,25)$. In 
tumor tissue, p63 is predominantly expressed in basal cell and squamous cell carcinomas, and not in adenocarcinomas, including those of the stomach and colon (7). A previous study reported that p63 was essential for embryological ectodermal differentiation, and that reduced expression of p63 had prognostic implications for patients with esophageal squamous cell carcinoma $(26,27)$. A recent study reported that p63 is essential for the proliferative potential of stem cells in stratified epithelia (10). Each year, studies elucidate the varying roles of p63 in human tissue.

Previously, we clarified the significance of p63 in human esophageal squamous cell carcinoma (15). The majority of such carcinomas exhibited diffuse or focal p63 expression. Regardless of tumor invasion, differentiation, regional lymph node metastasis and lymphatic/venous invasion, p63 immunoreactivity was observed in almost all cases. Based on these results, we suggested that the p63 gene plays principal roles in the carcinogenesis of human esophageal squamous cells and the growth of the carcinoma. In the present study, we tried to clarify the significance of p63 in esophageal Barrett's adenocarcinoma. The established risk factors for this adenocarcinoma are Barrett's esophagus, gastro-esophageal reflux, and obesity $(28,29)$. Some studies have described a relation between Barrett's esophagus and bile $(30,31)$. Adenocarcinoma of the esophagus almost always arises as a consequence of the neoplastic progression of Barrett's esophagus (32). Numerous markers of genetic and molecular processes have been proposed in the carcinogenesis of Barrett's esophagus (33). Jenkins et al and Morales et al reviewed the genetic pathways involved in the progression of Barrett's metaplasia to adenocarcinoma $(34,35)$. On the other hand, conventional clinical risk factors for the development of Barrett's adenocarcinoma are neither sensitive nor specific enough for the classification of individuals at high risk, e.g., sex, age, race and body-mass index (31).

p63 was less frequently detected in esophageal adenocarcinomas (13) and, here, focal expression of p63 was found in $45.8 \%$ of the esophageal Barrett's adenocarcinomas. Lymph node metastasis, lymphatic invasion and venous invasion were found significantly more often in the p63-positive cases. These findings suggest that p63 expression plays a significant role in the lymph node metastasis, lymphatic invasion and venous invasion of esophageal Barrett's adenocarcinoma cells, rather than in tumorigenesis, depth of invasion and differentiation. In conclusion, p63 expression was shown to be more useful as a predictor of lymph node metastasis than of any other clinicopathological feature of esophageal Barrett's adenocarcinoma.

\section{References}

1. Paull A, Trier JS, Dalton MD, Camp RC, Loeb P and Goyal RK: The histologic spectrum of Barrett's esophagus. N Engl J Med 295: 476-480, 1976.

2. Nishimaki T, Hölscher AH, Schüler M, Becker K, Muto T and Siewert JR: Chronic esophagitis and subsequent morphological changes of the esophageal mucosa in Barrett's esophagus: a histological study of esophagectomy specimens. Surg Today 24: 203-209, 1994.

3. Tselepis C, Perry I and Jankowski J: Barrett's esophagus: disregulation of cell cycling and intercellular adhesion in the metaplasia-dysplasia-carcinoma sequence. Digestion 61: 1-5, 2000.
4. Jankowski JA, Wright NA, Meltzer SJ, Triadafilopoulos G, Geboes K, Casson AG, Kerr D and Young LS: Molecular evolution of the metaplasia-dysplasia-adenocarcinoma sequence in the esophagus. Am J Pathol 154: 965-973, 1999.

5. Yamamoto S, Kijima H, Hara T, Kenmochi T, Kise Y, Tanaka H, Chino O, Shimada H, Tanaka M, Inokuchi S and Makuuchi H: Immunohistochemical mucin expression of short-segment Barrett's esophagus. Tokai J Exp Clin Med 28: 57-63, 2003.

6. Yamamoto S, Kijima H, Hara T, Chino O, Shimada H, Tanaka M, Inokuchi $\mathrm{S}$ and Makuuchi $\mathrm{H}$ : Mucin expression and proliferating cell index of esophageal Barrett's adenocarcinoma. Int J Mol Med 16: 375-380, 2005

7. Di Como CJ, Urist MJ, Babayan I, Drobnjak M, Hedvat CV, Teruya-Feldstein J, Pohar K, Hoos A and Cordon-Cardo C: p63 expression profiles in human normal and tumor tissues. Clin Cancer Res 8: 494-501, 2002.

8. Parsa R, Yang A, McKeon F and Green H: Association of p63 with proliferative potential in normal and neoplastic human keratinocytes. J Invest Dermatol 113: 1099-1105, 1999.

9. Yang A, Kaghad M, Wang Y, Gillett E, Fleming MD, Dötsch V, Andrews NC, Caput D and McKeon F: p63, a p53 homolog at 3q27-29, encodes multiple products with transactivating, deathinducing, and dominant-negative activities. Mol Cell 2: 305-316, 1998.

10. Senoo M, Pinto F, Crum CP and McKeon F: p63 is essential for the proliferative potential of stem cells in stratified epithelia. Cell 129: 523-536, 2007.

11. Quade BJ, Yang A, Wang Y, Sun D, Park J, Sheets EE, Cviko A, Federschneider JM, Peters R, McKeon FD and Crum CP: Expression of the p53 homologue p63 in early cervical neoplasia. Gynecol Oncol 80: 24-29, 2001.

12. Uramoto H, Sugio K, Oyama T, Nakata S, Ono K, Nozoe T and Yasumoto K: Expression of the p53 family in lung cancer. Anticancer Res 26: 1785-1790, 2006.

13. Glickman JN, Yang A, Shahsafaei A, McKeon F and Odze RD: Expression of p53-related protein p63 in the gastrointestinal tract and in esophageal metaplastic and neoplastic disorders. Hum Pathol 32: 1157-1165, 2001.

14. Carneiro FP, Ramalho LN, Britto-Garcia S, Ribeiro-Silva A and Zucoloto S: Immunohistochemical expression of p16, p53, and p63 in colorectal adenomas and adenocarcinomas. Dis Colon Rectum 49: 588-594, 2006.

15. Hara T, Kijima H, Yamamoto S, Kenmochi T, Kise Y, Tanaka H, Chino O, Shimada H, Takazawa K, Tanaka M, Inokuchi S and Makuuchi H: Ubiquitous p63 expression in human esophageal squamous cell carcinoma. Int J Mol Med 14: 169-173, 2004.

16. Sobin LH and Wittekind Ch (eds): Oesophagus. In: TMN Classification of Malignant Tumours. 6th edition. Wiles-Liss, Inc., New York, pp60-64, 2002.

17. Kijima H, Chino O, Oshiba G, Tanaka H, Kenmochi T, Kise Y, Shimada H, Abe Y, Tokunaga T, Yamazaki H, Nakamura M, Tanaka M, Makuuchi $\mathrm{H}$ and Ueyama Y: Immunohistochemical MUC1 (DF3 antigen) expression of human esophageal squamous cell carcinoma. Anticancer Res 21: 1285-1289, 2001.

18. Kijima H, Oshiba G, Kenmochi T, Kise Y, Tanaka H, Chino O, Shimada H, Ueyama Y, Tanaka M and Makuuchi H: Stromal CEA immunoreactivity is correlated with lymphatic invasion of human esophageal carcinoma. Int J Oncol 16: 677-682, 2000.

19. Tanaka H, Kijima H, Tokunaga T, Tajima T, Himeno S, Kenmochi T, Oshiba G, Kise Y, Nishi T, Chino O, Shimada H, Machimura T, Tanaka M and Makuuchi H: Frequent expression of inducible nitric oxide synthase in esophageal squamous cell carcinomas. Int J Oncol 14: 1069-1073, 1999.

20. Oshiba G, Kijima H, Himeno S, Kenmochi T, Kise Y, Tanaka H, Nishi T, Chino O, Shimada H, Machimura T, Tsuchida T, Nakamura M, Ueyama Y, Tanaka M, Tajima T and Makuuchi H: Stromal thrombospondin-1 expression is correlated with progression of esophageal squamous cell carcinomas. Anticancer Res 19: 4375-4378, 1999.

21. Chino O, Kijima H, Shimada H, Nishi T, Tanaka H, Kise Y, Kenmochi T, Himeno S, Machimura T, Tanaka M, Inokuchi S, Tajima T, Osamura RY and Makuuchi $\mathrm{H}$ : Accumulation of p53 in esophageal squamous cell carcinoma. Int J Mol Med 8: 359-363, 2001.

22. Hall PA, Woodman AC, Campbell SJ and Shepherd NA: Expression of the p53 homologue p63alpha and DeltaNp63 alpha in the neoplastic sequence of Barrett's oesophagus: correlation with morphology and p53 protein. Gut 49: 618-623, 2001. 
23. Geddert H, Kiel S, Heep HJ, Gabbert HE and Sarbia M: The role of p63 and deltaNp63 (p40) protein expression and gene amplification in esophageal carcinogenesis. Hum Pathol 34: 850-856, 2003.

24. Tsujita-Kyutoku M, Kiuchi K, Danbara N, Yuri T, Senzaki H and Tsubura A: p63 expression in normal human epidermis and epidermal appendages and their tumors. J Cutan Pathol 30: 11-17, 2003.

25. Senoo M, Tsuchiya I, Matsumura Y, Mori T, Saito Y, Kato H, Okamoto T and Habu S: Transcriptional dysregulation of the p73L/p63/p51/p40/KET gene in human squamous cell carcinomas: expression of delta Np73L, a novel dominantnegative isoform, and loss of expression of the potential tumour suppressor p51. Br J Cancer 84: 1235-1241, 2001.

26. Nylander K, Coates PJ and Hall PA: Characterization of the expression pattern of p63 alpha and delta Np63 alpha in benign and malignant oral epithelial lesions. Int J Cancer 87: 368-372, 2000.

27. Takahashi Y, Noguchi T, Takeno S, Kimura Y, Okubo M and Kawahara K: Reduced expression of p63 has prognostic implications for patients with esophageal squamous cell carcinoma. Oncol Rep 15: 323-328, 2006

28. Lagergren J: Adenocarcinoma of oesophagus: what exactly is the size of the problem and who is at risk? Gut 54: i1-i5, 2005.
29. Skacel M, Petras RE, Rybicki LA, Gramlich TL, Richter JE, Falk GW and Goldblum JR: p53 expression in low grade dysplasia in Barrett's esophagus: correlation with interobserver agreement and disease progression. Am J Gastroenterol 97: 2508-2513, 2002.

30. Hu Y, Jones C, Gellersen O, Williams VA, Watson TJ and Peters JH: Pathogenesis of Barrett esophagus: deoxycholic acid up-regulates goblet-specific gene MUC2 in concert with CDX2 in human esophageal cells. Arch Surg 142: 540-545, 2007.

31. Jankowski JA, Harrison RF, Perry I, Balkwill F and Tselepis C: Barrett's metaplasia. Lancet 356: 2079-2085, 2000.

32. Doak SH, Jenkins GJ, Parry EM, Griffiths AP, Shah V, Baxter JN and Parry JM: Characterisation of p53 status at the gene, chromosomal and protein levels in oesophageal adenocarcinoma. $\mathrm{Br} \mathbf{J}$ Cancer 89: 1729-1735, 2003.

33. Flejou JF: Barrett's oesophagus: from metaplasia to dysplasia and cancer. Gut 54: i6-i12, 2005.

34. Jenkins GJ, Doak SH, Parry JM, D'Souza FR, Griffiths AP and Baxter JN: Genetic pathways involved in the progression of Barrett's metaplasia to adenocarcinoma. Br J Surg 89: 824-837, 2002.

35. Morales CP, Souza RF and Spechler SJ: Hallmarks of cancer progression in Barrett's oesophagus. Lancet 360: 1587-1589, 2002 . 